DOI: 10.17707/AgricultForest.63.1.33

\title{
Mykola NAZARENKO
}

\section{INFLUENCE OF NITROSOALKYLUREAS ON WINTER WHEAT PLANTS AT FIRST GENERATION AFTER MUTAGEN ACTION}

The strategy of investigation combined the identification of genotypes carrying specific low-sensitive to mutagen factor using cytological and morphometrical analyzes screening of mutagen treated wheat populations with the approach of comparing different varieties by breeding methods to reveal its connections and differences, specific sensitive to mutagens effects on cell and plant level. The main purposes of investigations in this area were identification more suitable varieties for planting on mutagen-polluted area or as an object for mutation breeding.

Here we report cytogenetic, plant growth and development characteristics of mutation induction variability of the new wheat varieties and some relationships between means of plants grows and developments, morphometrical parameters, cytogenetic characteristics and different concentrations and types of mutagens at first generation after mutagen treatment.

Keywords: chemical mutagenesis, winter wheat, nitroso alkylureas, chromosomal aberration

\section{INTRODUCTION}

There were next reasons for conducting so types of investigations. Firstly, more than $40 \%$ of total Ukrainian territory is constantly under action of chemical pollution. For arable lands this measure is about $80 \%$, for Dnipropetrovsk region (as place of investigation) is about $90 \%$ (about a half of this territory at high or very high level). We apparently need in deployment of suit varieties for farming on these lands, especially for winter wheat because this zone is main for grain production in Ukraine. Secondary, we exploited chemical mutagenesis as a one of the main methods for breeding process of winter wheat (about $40 \%$ of wheat varieties, which official released in Ukraine are mutation varieties and $56 \%$ of these varieties have been obtained with chemical mutagens, for example new type of Ukrainian national varieties obtained by combined of field hybridization and nitrosoalkylureas action) (Nazarenko, 2015; Kharytonov et al, 2016). The improvement of crop productivity under stress conditions requires genotypes with good agronomic traits, drought tolerance and yield stability (Mohammadi and Abdulahi, 2016 (citate Blum, 1989); Popović,

\footnotetext{
${ }^{1}$ Mykola NAZARENKO (corresponding author: nik_nazarenko@ukr.net), Department of Plant Breeding and Seeds Management, Faculty of Agronomy, Dnipropetrovsk State Agrarian and Economic University, 49600, Dnipro, UKRAINE.
} 
2015; Popović et al, 2012; Djekic et al, 2013; Jankovic et al, 2015).

Nitrosoalkylureas are related to special group of mutagens "suoermutagens" (as classified by Rapoport). Special ability of this group is induction mutations on level of comparable mutagen without high damages, which influence on survival ability of plant material (Jovtcheva et al, 2002; Özel et al, 2015). Supermutagens induct 50-60 times more mutations than relevant by their consequences for surviving and plant development doses of gamma rays or fast neutrons (Albokari M., 2014).

Other feature (general for all chemical mutagens) is induction of target mutations (or site-specific mutations). It is depends on chemical nature of specific mutagen. That's why chemical mutagenesis is one of the important methods for modern genetics investigations (as for example for reverse genetics, for different types of tilling's methods). We can predict (in certain limits) types of future mutations and their rates (according to preferable DNA sequences for mutagen action) (Juchimiuk-Kwasniewska, 2002; Natarajan, 2002).

Mutagenic effects of chemicals have been assessed by both analysis of chromosomal aberrations (Rakhmatullina and Sanamyan, 2007) and investigation plant development and grows at first generation under field conditions. Chromosomal abnormalities in irradiated mitotic cells range from breaks, through exchanges, laggards and anaphase bridges, dicentric and centric ring formations, terminal fragments with telomeric signal at only one end and interstitial fragments that appear as double minutes without any telomeric signals (Rakhmatullina and Sanamyan, 2007). For crops like wheat, individual tillers (side branches) originate from different cells of the embryo of the treated seeds. If an aberration occurs in one of these cells, it will be carried in the tiller developed from that cell (Hossain and Alam, 2001; Huaili et al, 2005; Shu et al, 2011).

Mutated plants typically show reduced fertility, mainly caused by chromosomal rearrangements and genomic mutations during meiosis. We developed plant surviving, pollen fertility and yield structure for identification of mutagen depression (or stimulation) effects (Karthika, Subba, 2006; Nazarenko, 2015; Nazarenko and Kharytonov, 2016).

The main purposes of investigations in this area were determination of the chemical mutagen-polluted area suitability for agriculture, identification more suitable varieties for planting on proper chemical-polluted area or as a object for exploited in mutation breeding or genetics.

\section{MATERIAL AND METHODS}

Presoaking seeds of (in brackets method of obtaining varieties or used mutagens) Favoritka, Lasunya, Hurtovina (irradiation of initial material by gamma rays), line 418, Kolos Mironovschiny (field hybridization), Sonechko (chemical mutagenesis, nitrosodimethilurea (NDMU) 0.005\%) and Kalinova (chemical mutagenesis, DAB 0.1\%), Voloshkova (termomutagenesis - low plus temperature at plant development stage of vernalizaion has been used as mutagen 
factor) of winter wheat (Triticum aestivum L.) were subjected to chemical mutagens: nitrosomethilurea (NMU) 0.0125 and $0.025 \%$, nitrosoethilurea (NEU) - 0.01 та $0.025 \%$. Exposure to chemical mutagens lasts 18 hours. These concentrations and exposure are optimal for the breeding process that has been repeatedly established earlier (Shu et al, 2011). Non-treated varieties were used as a check.

Treated seeds were grown in rows with inter and intra-row spacing of 50 and $30 \mathrm{~cm}$, respectively, to raise the $M_{1}$ population. The untreated seeds of mother varieties (parental line/variety) were also planted after every ten rows as control for comparison with the $\mathrm{M}_{1}$ population. $\mathrm{M}_{1}$ plant rows were grown in three replications with check-rows of untreated varieties in every ten-row interval. Data on seed germination and surviving plants were recorded considering whole plots of $\mathrm{M}_{1}$ population. Data on yield structure components (plant height, general number of culms, number of productive culms, spike length, spikelets per spike, number of grain per spike, grain weight per spike and plant, 1000 grains weight) were taken from 50 randomly selected plants of each treatment representing more or less all types of morphological plants (Sanamyan et all, 2010).

The seeds used in this study were of the $\mathrm{M}_{0}$ generation. After mutagen treatment dry seeds were germinated in Petri dishes under $24-72$ hours (depends on presoaking and mutagen action), temperature $+25^{\circ} \mathrm{C}$. After wards central primary roots were cut and fixed in solution of alcohol and acetic acid (in proportion 3:1) for 24 hours. Fixation material was stored in $70 \%$ alcohol solution under temperature $2{ }^{\circ} \mathrm{C}(20-25$ roots per variant). Cytological analysis was carried out by the standard method at temporary press-time preparations of root tips $(1-1.5 \mathrm{~mm})$ stained with acetocarmine (has been prepared by Remsderh). Tissue maceration (if it needs for analysis) was carried out at $45 \%$ solution of acetic acid (during 5 minutes on bane-marie under $60^{\circ} \mathrm{C}$ ). Anaphase of cell division was observed by light microscope JNAVAL. No less than 1000 cells in proper phases of mitosis were observed in each variant (Lifang et al, 2001; Rank et al, 2002,; Natarajan, 2005; Nikolova et al, 2015).

Mathematical processing of the results was performed by the method of analysis of variance, the variability of the mean difference was evaluated by ANOVA. Used the standard tools of the program Statistica 8.0 for factor analysis (ANOVA module).

\section{RESULTS AND DISCUSSION}

\section{Analysis of grows and development of plants}

In $\mathrm{M}_{1}$ population, observations were recorded seed germination and plant surviving, pollen fertility, plant height, spikes/plant, spike length, kernels/spike, 1000 -grain weight, yield/plant (table $1-3)$. Standard error $( \pm$ SE) values of the treated populations are at tables too. 
The results on germination of seeds, survival rate of plants derived from treated and untreated seeds are tabulated (Table 1). Germination and survival abilities of seeds reduce compared to untreated seeds of the initial variety in all cases.

Germination and survival abilities of seeds reduce compared to untreated seeds of the initial variety in all cases except one (Sonechko, NEU). Plant survival ability ranges from 68 (Sonechko, Kalinova) to 63\% (Lasunya) at $0.025 \% \mathrm{NMU}$, while it ranged from 98 to $92 \%$ under untreated control. As for the impact of chemical mutagens on the germination and survival abilities, it is the usual effect in plants for most crops previously observed by many researchers in wheat as well (Bolzarn, Bianchi, 2006). However, we can see that chemical mutagens are more specific at the comparable effects than the gamma-rays. Some varieties have been shown this parameter without significant difference from check (Voloskova, Hurtovina, Sonechko, NEU $0.01 \%$ ).

Table 1. Main parameters of grown of winter wheat plants at $M_{1}$ generation

\begin{tabular}{|l|c|c|c|c|}
\hline \multicolumn{1}{|c|}{ Trial } & $\begin{array}{c}\text { Germination, } \\
\text { Variety }\end{array}$ & $\begin{array}{c}\text { Survival after } \\
\text { winter, } \%\end{array}$ & $\begin{array}{c}\text { Germination, } \\
\%\end{array}$ & $\begin{array}{c}\text { Survival after } \\
\text { winter, } \%\end{array}$ \\
\hline Check & $98 \pm 0.57$ & $91 \pm 0.93$ & $94 \pm 0.94$ & $88 \pm 0.98$ \\
\hline NMU, 0.0125\% & $80 \pm 1.05^{*}$ & $78 \pm 1.01^{*}$ & $74 \pm 0.61^{*}$ & $73 \pm 0.56^{*}$ \\
\hline NMU, 0.025\% & $66 \pm 1.01^{*}$ & $65 \pm 0.87^{*}$ & $69 \pm 0.49^{*}$ & $68 \pm 0.48^{*}$ \\
\hline NEU, 0.01\% & $81 \pm 0.94^{*}$ & $81 \pm 0.94^{*}$ & $82 \pm 0.92^{*}$ & $82 \pm 0.92^{*}$ \\
\hline NEU, 0.025\% & $74 \pm 0.70^{*}$ & $73 \pm 0.67^{*}$ & $76 \pm 0.80^{*}$ & $76 \pm 0.78^{*}$ \\
\hline Variety & \multicolumn{2}{|c|}{ Voloshkova } & \multicolumn{2}{c|}{ Sonechko } \\
\hline Check & $92 \pm 0.57$ & $87 \pm 0.93$ & $94 \pm 0.94$ & $89 \pm 0.98$ \\
\hline NMU, 0.0125\% & $78 \pm 0.90^{*}$ & $78 \pm 0.81^{*}$ & $79 \pm 1.02^{*}$ & $78 \pm 0.82^{*}$ \\
\hline NMU, 0.025\% & $69 \pm 0.70^{*}$ & $67 \pm 0.69^{*}$ & $69 \pm 1.04^{*}$ & $67 \pm 0.94^{*}$ \\
\hline NEU, 0.01\% & $90 \pm 0.81$ & $88 \pm 0.74$ & $87 \pm 1.10^{*}$ & $87 \pm 1.0$ \\
\hline NEU, 0.025\% & $82 \pm 0.78^{*}$ & $80 \pm 0.68^{*}$ & $79 \pm 1.40^{*}$ & $78 \pm 1.25^{*}$ \\
\hline Variety & \multicolumn{3}{|c|}{ Favoritka } & \multicolumn{2}{c|}{ Hurtovina } \\
\hline Check & $98 \pm 0.57$ & $91 \pm 0.93$ & $92 \pm 0.94$ & $84 \pm 0.98$ \\
\hline NMU, 0.0125\% & $79 \pm 0.93^{*}$ & $78 \pm 0.87^{*}$ & $78 \pm 1.01^{*}$ & $77 \pm 0.93^{*}$ \\
\hline NMU, 0.025\% & $70 \pm 1.30^{*}$ & $69 \pm 1.0^{*}$ & $68 \pm 0.76^{*}$ & $68 \pm 0.74^{*}$ \\
\hline NEU, 0.01\% & $88 \pm 0.82^{*}$ & $87 \pm 0.74^{*}$ & $86 \pm 0.90^{*}$ & $85 \pm 0.36$ \\
\hline NEU, 0.025\% & $82 \pm 1.04^{*}$ & $80 \pm 0.98^{*}$ & $81 \pm 1.02^{*}$ & $79 \pm 0.99^{*}$ \\
\hline Variety & \multicolumn{3}{|c|}{ Lasunya } & \multicolumn{3}{c|}{ Line 418} \\
\hline Check & $98 \pm 0.57$ & $94 \pm 0.93$ & $93 \pm 0.94$ & $92 \pm 0.98$ \\
\hline NMU, 0.0125\% & $76 \pm 1.20^{*}$ & $75 \pm 1.0^{*}$ & $82 \pm 1.40^{*}$ & $80 \pm 1.2^{*}$ \\
\hline NMU, 0.025\% & $64 \pm 1.50^{*}$ & $63 \pm 1.1^{*}$ & $73 \pm 0.81^{*}$ & $68 \pm 0.34^{*}$ \\
\hline NEU, 0.01\% & $88 \pm 1.10^{*}$ & $85 \pm 0.88^{*}$ & $88 \pm 1.12^{*}$ & $85 \pm 1.02^{*}$ \\
\hline NEU, 0.025\% & $81 \pm 1.30^{*}$ & $79 \pm 1.1^{*}$ & $78 \pm 1.50^{*}$ & $78 \pm 1.04^{*}$ \\
\hline
\end{tabular}

* - difference is statistically significance from check at $\mathrm{P}_{0.05}$

In general, the correlation between the dose value and survival abilities of plants is at the level of -0.8 .

Correlation between the concentration of mutagens and pollen fertility was -0.85 . We cannot see any difference in plant response on mutagen action, only 
heightening of pollen sterility depended on concentration on mutagen. NMU was more active in induce decreasing of male sterility.

Table 2. Pollen fertility after mutagen action, $\%$

\begin{tabular}{|c|c|c|c|c|c|c|c|c|}
\hline Trial & 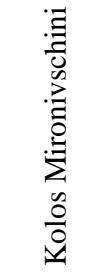 & 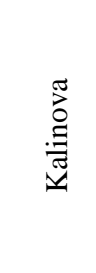 & $\begin{array}{l}\frac{\tilde{a}}{0} \\
\frac{0}{7} \\
\frac{0}{0} \\
\frac{0}{0} \\
>\end{array}$ & 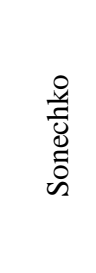 & 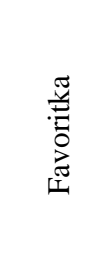 & 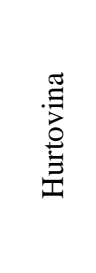 & 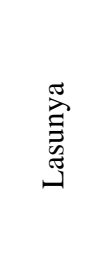 & $\begin{array}{l}\stackrel{\infty}{\nabla} \\
\stackrel{\Xi}{\Xi}\end{array}$ \\
\hline Check & 95.0 & 93.1 & 89.7 & 96.7 & 95.7 & 98.6 & 96.8 & 93.0 \\
\hline NMU, $0.0125 \%$ & $89.1^{*}$ & $84.3 *$ & 87.6 & $79.8^{*}$ & $90.1^{*}$ & $88.5^{*}$ & $89.2 *$ & $89.6^{*}$ \\
\hline NMU, $0.025 \%$ & $85.2 *$ & $72.3 *$ & $84.3 *$ & $64.2 *$ & $85.4 *$ & $84.4 *$ & $86.6^{*}$ & $85.4^{*}$ \\
\hline NEU, $0.01 \%$ & $90.2 *$ & $88.0 *$ & $88.9 *$ & $84.6 *$ & $93.0 *$ & $95.4 *$ & $93.2 *$ & $90.1^{*}$ \\
\hline NEU, $0.025 \%$ & 88.4 & $84.2 *$ & $87.0 *$ & $80.1^{*}$ & $90.6^{*}$ & $88.7 *$ & $90.8 *$ & $88.3^{*}$ \\
\hline
\end{tabular}

All parameters of the crop yield structure have been studied. Components such as plant height, 1000 grain weight, grain weight per plant, number of grains per spike, grain weight per spike, general number of culms, number of productive culms, spike lengths have been developed. Only four (plant height, grain weight per spike, grain weight per plant and 1000 grain weight) showed statistically difference level of mutagen depression under any dose action. And for this type of mutagens grain weight per plant is more reliability parameter in assessment of mutagen depression than grain weight per plant (in case of gamma-rays this index wasn't sufficient for correct evolution (Nazarenko, 2016).

Regarding the plant height, correlation between the concentration and the indicator constituted -0.82 , (high invert correlation). This parameter decreases if the concentration increases. Gradual decrease in height is a tendency, but we ran on with substantial differences between the varieties. Sonechko and Kalinova has been shown stimulation effect after NEU 0.01 action and plant height was on level of check after NEU 0.025 .

The indicator of grain weight per spike was so informative; weight was falling statistically valid with every increase in dose. Sonechko responded to mutagenic effect in the same manner (non-depression at NMU 0,0125\%). The correlation coefficient was -0.8 .

Due to the grain weight per plant, correlation between the concentration and the parameter is -0.84 , (high invert correlation). This parameter decreases if the concentration increases. We cannot see depression in case of Kalinova and in one concentration (same as for previous parameter) for Sonechko.

The thousand grain weight is the most informative indicator (similar as gamma-rays). Depression value at each concentration is clear and statistically 
valid. The correlation coefficient was -0.89 . Variety Kalinova was non-depressed under NMU $0.0125 \%$.

Sonechko and Kalinova are less sensitive to both mutagens in compare with other genotypes for all variants.

Table 3. Correlation between gamma-rays dose and some components of yield structure of $\mathrm{M}_{1}$ varieties

\begin{tabular}{|c|c|c|c|c|c|c|c|c|}
\hline $\begin{array}{c}\text { Paramet } \\
\text { er }\end{array}$ & $\begin{array}{c}\text { Plant } \\
\text { height }\end{array}$ & $\begin{array}{c}\text { No. of } \\
\text { culms }\end{array}$ & $\begin{array}{c}\text { Spike } \\
\text { lengths }\end{array}$ & $\begin{array}{c}\text { No. of } \\
\text { spikelet } \\
\text { s }\end{array}$ & $\begin{array}{c}\text { No. of } \\
\text { grains } \\
\text { per } \\
\text { spike }\end{array}$ & $\begin{array}{c}\text { Grain } \\
\text { weig } \\
\text { ht per } \\
\text { spike }\end{array}$ & $\begin{array}{c}\text { Grain } \\
\text { weight } \\
\text { per } \\
\text { plant }\end{array}$ & $\begin{array}{c}1000 \\
\text { grain } \\
\text { weig } \\
\text { ht }\end{array}$ \\
\hline Dose & -0.82 & -0.22 & 0.18 & 0.23 & -0.60 & -0.80 & -0.84 & -0.89 \\
\hline
\end{tabular}

\section{Chromosomal aberrations analysis}

The results of our investigation are represented at table 4 (total number of observing mitosis, number of division cells with chromosomal aberrations, general frequency of aberrations). Standard error ( \pm SE) values of the treated populations are at tables too. As we can see from table 4 frequencies were changed from 4.44 (Sonechko, NEU $0.01 \%$ ) to 22.69 (Voloshkova, NMU 0.025 $\%)$ percents from total number of mitosis. All the variables are statistically significantly different from each other and from the check.

Variety Sonechko is the most resistance genotype for mutagen action with highest level of difference and this variety was obtained with nitrosoalkylureas action (mutagen was other, but it's belong to this type of mutagens). NMU initiated more rates of chromosome aberrations, than NEU.

After spectra of chromosomal aberrations had been investigated next types was identified: chromosomal bridges and double-bridges, fragments of chromosomes and double-fragments, micronucleus, lagging chromosomes. Cases with two or more types of aberrations in one cell and fragments-bridges ratio were calculated separately (Table 4).

After this date had been analyzed we identified some correlations between mutagen concentrations and parameters of spectra. Quantity of any type of chromosomal aberrations was increased with concentration increased (correlation coefficients $0.7-0.8$, it was less than for gamma-rays, but enough for correct asset (Nazarenko, 2015). In our past investigations gamma-rays induced more bridges than fragments (fragments-bridges ratio lower than 1) (Nazarenko, Kharitonov, 2016). After chemical mutagens more fragments and doublefagments have been observed (fragments-bridges ratio more than 1). These parameters can be used for mutagen nature identification, but only for limit kinds of chemical substances. As we can see, we will be able to use this parameter for identify nature of unknown mutagen for nitrosoalkylureas agents. We know from other investigation that it was not correct (in some variants) for other type of supermutagens. Both mutagens (NMU and NEU) induced similar types of aberrations in similar rate. Amount of any types of chromosome's changes were increased with concentrations growth, but in case of complicated aberrations, 
lagging chromosomes and micronucleus it was not significant. More rates of complicated aberrations and micronucleus are characterized for nitrosoalkylureas than for gamma-rays (Zhang et al, 2015).

Table 4. Frequency of chromosomal aberrations in $\mathrm{M}_{1}$ generation of winter

\begin{tabular}{|c|c|c|c|c|c|c|}
\hline \multirow{3}{*}{ Variable } & \multirow{2}{*}{$\begin{array}{l}\text { Mitosis, } \\
\text { number }\end{array}$} & \multicolumn{2}{|c|}{$\begin{array}{c}\text { Chromosomal } \\
\text { aberrations }\end{array}$} & \multirow{2}{*}{$\begin{array}{c}\text { Mitosis, } \\
\text { number }\end{array}$} & \multicolumn{2}{|c|}{$\begin{array}{c}\text { Chromosomal } \\
\text { aberrations }\end{array}$} \\
\hline & & n. & $\%$ & & $\mathrm{n}$. & $\%$ \\
\hline & \multicolumn{3}{|c|}{ Favoritka } & \multicolumn{3}{|c|}{ Line 418} \\
\hline Check & 984 & 19 & $1.93 \pm 0.31$ & 962 & 11 & $1.14 \pm 0.11$ \\
\hline NMU, $0.0125 \%$ & 1048 & 139 & $13.26 \pm 1.29 *$ & 906 & 106 & $11.70 \pm 1.12 *$ \\
\hline NMU, $0.025 \%$ & 934 & 179 & $19.17 \pm 1,48^{*}$ & 983 & 188 & $19.12 \pm 1.57 *$ \\
\hline NEU, $0.01 \%$ & 1020 & 91 & $8.92 \pm 0.89 *$ & 1021 & 93 & $9.11 \pm 0.84 *$ \\
\hline \multirow[t]{2}{*}{ NEU, $0.025 \%$} & 940 & 141 & $15.00 \pm 1.39 *$ & 900 & 156 & $17.33 \pm 1.22 *$ \\
\hline & \multicolumn{3}{|c|}{ Lasunya } & \multicolumn{3}{|c|}{ Hurtovina } \\
\hline Check & 1056 & 15 & $1.42 \pm 0.19$ & 1034 & 12 & $1.16 \pm 0.11$ \\
\hline NMU, $0.0125 \%$ & 1019 & 121 & $11.89 \pm 1.28^{*}$ & 1005 & 143 & $14.22 \pm 1.37 *$ \\
\hline NMU, $0.025 \%$ & 844 & 161 & $19.09 \pm 1.43^{*}$ & 1022 & 223 & $21.83 \pm 1.59 *$ \\
\hline NEU, $0.01 \%$ & 1003 & 97 & $9.67 \pm 0.92 *$ & 1018 & 103 & $10.12 \pm 0.99 *$ \\
\hline \multirow[t]{2}{*}{ NEU, $0.025 \%$} & 1015 & 159 & $15.67 \pm 1.33^{*}$ & 1024 & 184 & $17.97 \pm 1.42 *$ \\
\hline & \multicolumn{3}{|c|}{ Sonechko } & \multicolumn{3}{|c|}{ Voloshkova } \\
\hline Check & 1026 & 8 & $0.78 \pm 0.04$ & 1003 & 31 & $3.09 \pm 0.34$ \\
\hline NMU, $0.0125 \%$ & 1027 & 56 & $5.45 \pm 0.34 *$ & 1002 & 142 & $14.17 \pm 1.17 *$ \\
\hline NMU, $0.025 \%$ & 981 & 108 & $11.01 \pm 0.99 *$ & 912 & 207 & $22.69 \pm 1.64^{*}$ \\
\hline NEU, $0.01 \%$ & 1013 & 45 & $4.44 \pm 0.44 *$ & 1005 & 116 & $11.54 \pm 1.02 *$ \\
\hline \multirow[t]{2}{*}{ NEU, $0.025 \%$} & 972 & 97 & $9.98 \pm 0.98 *$ & 976 & 169 & $17.32 \pm 1.44 *$ \\
\hline & \multicolumn{3}{|c|}{ Kalinova } & \multicolumn{3}{|c|}{ Kolos Mironivschini } \\
\hline Check & 1047 & 9 & $0.86 \pm 0.11$ & 909 & 10 & $1.10 \pm 0.13$ \\
\hline NMU, $0.0125 \%$ & 1009 & 106 & $10.51 \pm 1.07 *$ & 1016 & 129 & $12.70 \pm 1.22^{*}$ \\
\hline NMU, $0.025 \%$ & 851 & 133 & $15.63 \pm 1.27 *$ & 917 & 190 & $20.72 \pm 1.61 *$ \\
\hline NEU, $0.01 \%$ & 984 & 78 & $7.93 \pm 0.64 *$ & 1014 & 89 & $8.78 \pm 0.82 *$ \\
\hline NEU, $0.025 \%$ & 846 & 135 & $15.96 \pm 1.33^{*}$ & 951 & 155 & $16.30 \pm 1.34 *$ \\
\hline
\end{tabular}

* - difference statistically significant on $\mathrm{P}_{0,01}$

In some preliminary works researches mentioned about exploited of double-fragment rate as measure for chemical mutagens efficiency on cell level (Natarajan, 2005; Shu et al, 2011), but no one said about dominance of fragments regarding to nitrosoalkylureas and about applying fragments-bridges ratio for mutagen nature identification. Our method enables to solve this problem and we sure in effectiveness one under any conditions for any plant object. 
Thereby, we propose this parameter (prevalence of fragments under bridges as fragments-bridges ratio) for mutagen nature identification. Complicated (or combined) aberrations are more typical for chemical mutagens than for physical. Genotype, obtained with nitrosoalkylureas is less sensitive for repeated action of the same mutagen. Previous rule for gamma-rays was confirmed for one type of chemical supermutagens too.

\section{CONCLUSIONS}

The most informative parameters to determine the degree of mutagenic depression in the first generation for plant growth and development were germination and survival rates, pollen sterility. However, distinctly of gammarays, we have four inconsiderate morphometrical parameters for mutagen depression identification. There are plant height, grain weight per spike, grain weight per plant and 1000 grain weight. We developed stimulation effect in case of NEU $0.01 \%$ for some varieties. The least level of mutagen depression by morphometrical indicators we observed in case of Sonechko and Kalinova. Therefore, chemical mutation varieties are less sensible for to same chemical mutagens

Chemical mutations varieties were less sensitive to same chemical mutagens. As we can see varieties Sonecko and Kalinova are more preferable for growth under this action. We can predict less number of mutations when these varieties would be used for mutation breeding purposes.

The higher rates of chromosomal aberrations are typical for varieties obtained by used field hybridization without any mutagen treatment or when initial material for breeding has been changed by low temperature action (variety Voloshkova).

Comparing between bridges and fragments is a reliable mean for identification of mutagen nature (chemical or gamma-rays). In first case more fragments have been induction, in second - bridges.

In general, the frequency of any type of chromosomal aberrations is linearly increased with increase concentrations of the mutagen.

As object for mutation breeding we propose varieties obtained by used field hybridization without any mutagen treatment or mutation varieties which obtained with other mutagen than using in breeding program. We offer for planting in mutagen nitrosoalkylureas pollution areas chemical mutation varieties like as Sonechko and Kalinova.

\section{REFERENCES}

Albokari M., 2014. Induction of mutants in durum wheat using gamma irradiation. In: Pakistan Journal of Botany, 46, 317-324.

Bolzarn, A. D., Bianchi, M. S., 2006. Telomeres, interstitial telomeric repeat sequences, and chromosomal aberrations. In: Mutation Research, 612, $189-214$.

Jovtcheva, G., Stergiosa, M., Schubert, I., 2002. A comparison of N-methyl-Nnitrosourea-induced chromatid aberrations and micronuclei in barley meristems using FISH techniques . In: Mutation Research, 517, 47-51. 
Juchimiuk-Kwasniewska, J., Brodziak, L., Maluszynska, J., 2011. FISH in analysis of gamma ray-induced micronuclei formation in barley. In: Journal of Applied Genetics, $52,23-29$.

Hossain M. F., Alam M. S., 2001. Effect of gamma irradiation on the callus, developed from indica rise. In: Pakistan Journal of Biological Sciences, 6, 670-671.

Huaili Q., Lanming X., Fei H., 2005. Biological effect of the seeds of Arabidopsis thaliana irradiated by $\mathrm{MeV}$ protons. In: Radiation Effects \& Defects in Solids, 160, $131-136$.

Karthika I R., Subba B., 2006. Effect of Gama Rays and EMS on Two varieties of Soybean. In: Asian Journal of Biological Sciences, 5, 721-724.

Kharytonov, M.M., Pashova, V. T., Mitsik, O.O., Nazarenko, M.M., Bagorka, M.O., 2016 Estimation of winter wheat varieties suitability for difference growth of landscape conditions. In: Agricultural and mechanical engineering: Materials of International Symposium ISB-INMA TECH (Bucharest, 27-29 October, 2016), Buchares, INMA, $401-406$.

Lifang Y., Zengliang W., 2001. Radiobiological effects of a low-energy ion beam on wheat. In: Radiat Environ Biophys, 40, 53-57.

Natarajan, A.T., 2002. Chromosome aberrations: past, present and future. In: Mutation Research, 504, 3-16.

Natarajan, A.T., 2005. Chromosome aberrations: Plants to human and feulgen to FISH. In: Current Science 89, 335-340.

Nazarenko, M., 2015. Osobennosti vozdeystviya gamma-luchey na hromosomnyiy apparat kletki na primere pshenitsyi myagkoy ozimoy [The frequency and spectrum of chromosomal aberrations in root meristem cells of wheat under the action of mutagens]. Tambow State Unuversity Reports. Ser.: Natural and Technical sciences, 2, 449-452, (in Russian).

Nazarenko, M., 2015. Negativnyie posledstviya mutagennogo vozdeystviya [Peculiarities of negative consequences of mutagen action]. In: Ecological Genetics, 4, 25-26. (in Russian)

Nazarenko, M., 2016. Parameters of winter wheat growing and development after mutagen action. In: Bulletin of Transilvania University of Brasov - series II - Forestry, Wood Industry, Agricultural, Food Engineering, 9 (58), 2, 109-116.

Nazarenko, M., Kharytonov, M., 2016. Characterization of wheat mutagen depression after gamma-rays irradiated. In: Agriculture and Forestry, 62, 4, 267-276.

Nikolova, I., Georgieva, M., Kruppa, K., Molnor-Long, M., Liu, L., Manova, V., Stoilov, L., 2015. Cytogenetic effects in barley root apical meristem after exposure of dry seeds to lithium ion beams. In: Genetics and Plant Physiology, 5, 3-9.

Özel, H.B., Kirdar, E., Bilir, N. 2015. The effects of magnetic field on germination of the seeds of oriental beech (Fagus orientalis Lipsky.) and growth of seedlings. Agriculture and Forestry, 61 (3): 195-206.

Popović, V. (2015). The concept, classification and importance of biological resources in agriculture. (Ed) Milovanovic J., Đorđević S.: Conservation and enhancement of biological esources in the service of ecoremediation. Monograph. Belgrade. ISBN 97886-86859-41-9; 29-51; 1-407.

Popović, V., Malešević, M., Glamočlija, Dj., Vučković, S., Tatić, M., Mladenović, G., Hristov, N. (2012): Effect of agro-ecological factors on wheat seed production. Scientific Journal of Univerzity of Szeged, Faculty Agriculture. Hodmezovasarhely, Vol. 6 (2),150-157. 
Đekić, V., Staletić, M., Jelić, M., Popović, V., Branković, S. 2013. The stability properties of wheat production on acid soil. $4^{\text {th }}$ International Symposium "Agrosym 2013", Jahorina, p. 84-89.

Janković, S., Ikanović, J., Popović, V., Rakić, S., Pavlović, S., Ugrenović, V., Simić, D, Dončić, D. (2015): Morphological and productive traits of spelt wheat - Triticum spelta L. "Agriculture and Forestry", Podgorica, Vol. 61, 2, 173-182.

Mohammadi, R., Abdulahi, A. (2016): Selection for traits associated with drought tolerance in durum wheat. Agriculture and Forestry, 62 (3): 139-150.

Rakhmatullina, E.M., Sanamyan, M.F., 2007. Estimation of efficiency of seed irradiation by thermal neutrons for inducing chromosomal aberration in $\mathrm{M}_{2}$ of cotton Gossypium hirsutum L. In: Russian Journal of Genetics 43(5), 518-524.

Rank, J., Lopez, L.C., Nielsen M.H., 2002. Genotoxicity of maleic hydrazide, acridine and DEHP in Allium cepa root cells performed by two different laboratories. In: Hereditas 136, 13-18.

Sanamyan, M. F., Petlyakoval, J. E., Sharipoval, E. A., Abdurakhmonov, I. Y., 2010. Morphological characteristics and identification of new monosomic stocks for cotton (Gossypium hirsutum L.) In: Advances in Bioscience and Biotechnology 1, 372-383.

Shu, Q.Y., Forster B.P., Nakagava H., 2011 Plant Mutation breeding and Biotechnology, Vienna, CABI publishing.

Zhang, J., Jiang, Y., Guo, Y., Li, G., Yang, Z., Xu, D., 2015. Identification of Novel Chromosomal Aberrations Induced by 60Co- $\gamma$-Irradiation in Wheat-Dasypyrum villosum Lines. In: International Journal of Molecular Sciences, 16, 29787-29796. 